\title{
Characterizing aerosol optical depth measurements and forecasts of Saharan dust events at Camagüey, Cuba, during July 2009
}

\section{Caracterización de las mediciones y los pronósticos del espesor óptico de aerosoles de los eventos de polvo Sahariano en Camagüey, Cuba, durante Julio del 2009}

\author{
Juan Carlos Antuña(1), Victoria Cachorro(2,S), René Estevan(1), Ángel de Frutos(2,S), \\ Boris Barja(1), Yasmine Benouna(2), Benjamín Torres(2), David Fuertes ${ }^{(2)}$, \\ Ramiro González(2),Carlos Toledano(2,S), George Kallos(3), Spyrou Cristos(3) \\ 1. Grupo de Óptica Atmosférica de Camagüey, Centro Meteorológico de Camagüey, Camagüey, Cuba. \\ 2. Grupo de Óptica Atmosférica, Universidad de Valladolid, Spain. \\ 3. Department of Applied Physics, University of Athens, Greece.
${ }^{(*}$ Email: anadelia@caonao.cu
S: miembro de SEDOPTICA / SEDOPTICA member
Recibido / Received: 13/07/2012. Revisado / Revised: 11/10/2012. Aceptado / Accepted: 17/10/2012. \\ DOI: http://dx.doi.org/10.7149/OPA.45.4.415
}

\begin{abstract}
:
Saharan dust aerosol optical depth (AOD) sun-photometer measurements conducted at Camagüey, Cuba, during July 2009 are compared with the SKIRON model AOD forecasts and the AOD MODIS measurements. The differences for the daily mean AOD values from SKIRON forecasts and from MODIS measurements (both Terra and Aqua) are lower than the differences of the daily AOD maximums. The results demonstrate the capabilities for developing an alert and tracking system for Saharan dust events across the Atlantic.
\end{abstract}

Key words: Saharan Dust, Aerosols, AOD, SKIRON model, MODIS.

\section{RESUMEN:}

Se comparan las mediciones del espesor óptico de aerosoles (AOD) de polvo del Sahara realizadas en Camagüey, Cuba, durante Julio del 2009 con valores pronosticados de AOD por el modelo SKIRON y con mediciones de AOD realizadas por los satélites MODIS. Las diferencias entre las medias diarias del AOD pronosticado por SKIRON y medido por MODIS (tanto Terra como Aqua) son menores que las diferencias entre los máximos diarios. Los resultados demuestran la capacidad de desarrollar un sistema de alerta y seguimiento de los eventos de polvo del Sahara a través del Atlántico.

Palabras clave: Polvo del Sahara, Aerosoles, AOD, Modelo SKIRON, MODIS.

\section{REFERENCIAS Y ENLACES / REFERENCES AND LINKS}

[1]. Y. J. Kaufman, I. Koren, L. A. Remer, D. Tanré, P. Ginoux, S. Fan, "Dust transport and deposition observed from the Terra-Moderate Resolution Imaging Spectroradiometer (MODIS) spacecraft over the Atlantic Ocean", J. Geophys. Res. 110, D10S12 (2005).

[2]. Y. Ben-Ami, I. Koren, O. Altaratz, "Patterns of Saharan dust transport over the Atlantic: winter vs. summer, based on CALIPSO first year data", Atmos. Chem. Phys. 9, 13177-13198 (2009).

[3]. http://nansen.ipsl.jussieu.fr/AEROCOM/

[4]. N. Huneeus, M. Schulz, Y. Balkanski, J. Griesfeller, J. Prospero, S. Kinne, S. Bauer, O. Boucher, M. Chin, F. Dentener, T. Diehl, R. Easter, D. Fillmore, S. Ghan, P. Ginoux, A. Grini, L. Horowitz, D. Koch, M. C. Krol, W. Landing, X. Liu, N. Mahowald, R. Miller, J.-J. Morcrette, G. Myhre, J. Penner, J. Perlwitz, P. Stier, T. Takemura, C. S. Zender, "Global dust model intercomparison in AeroCom phase I", Atmos. Chem. Phys. 11, 7781-7816 (2011). 
[5]. R. Estevan, J. C. Antuña, B. Barja, V. E. Cachorro, Á. M. de Frutos, A. Berjón, C. Toledano, B. Torres, R. Rodrígo, T. A. Hernández, C. E. Hernández, "Preliminary results of aerosols measurements with sun photometer at Camagüey, Cuba”, Opt. Pura Apl. 44, 99-106 (2011).

[6]. G. Kallos, C. Spyrou, M. Astitha, C. Mitsakou, S. Solomos, J. Kushta, I. Pytharoulis, P. Katsafados, E. Mavromatidis, N. Papantoniou, G. Vlastou, "Ten-year operational dust forecasting - Recent model development and future plans", IOP Conf. Series: Earth and Environmental Science 7, 012012 (2009).

[7]. R. Levy, L. Remer, D. Tanré, S. Mattoo, Y. Kaufman, “Algorithm for remote sensing of tropospheric aerosol over dark targets from MODIS: Collections 005 and 051: Revision 2", February 2009, MODIS Algorithm Theoretical Basis Document (2009).

\section{Introduction}

Recent studies using state of the art satellite information showed that every year $240 \pm 80 \mathrm{Tg}$ of dust are transported from Africa in the latitude band $20^{\circ} \mathrm{S}-30^{\circ} \mathrm{N}$. From that amount $50 \pm 15 \mathrm{Tg}$ are deposited in the Amazon basin and $50 \pm 25 \mathrm{Tg}$ arrive to the Caribbean [1,2]. Those enormous amounts of aerosols have an important impact in human activities.

There have been important progresses in producing better model forecasts of dust globally and several validation studies have been conducted in recent years. One example is the AeroCom project [3]. One of its recent reports established the existence of large differences among the global models that simulate the dust cycle and its impact on climate. It was also reported that the simulation of climatologically values of dust properties like the AOD differs from the observations within a factor of two [4]. Further comparisons are under way.

The GOAC team (Grupo de Óptica Atmosférica de Camagüey), in cooperation with scientists from several institutions, is developing a service for alert-tracking the Saharan dust transported over the Atlantic to the Wider Caribbean. The core idea of the service is to provide, to each one of the countries of the Wider Caribbean, local notices of the future arrival of Saharan dust to this area combined with updates of the current position of the dust air masses. It will combine existing numerical modeling of the Saharan dust transport with satellite and surface observations. Those sources of information are the SKIRON model AOD forecasts, the derived AOD from MODIS (both from Terra and Aqua) and the derived sun-photometer AOD. The purpose of the present comparison is to have a preliminary estimation of the magnitudes of the differences between the AOD sunphotometer measurements at Camagüey and the coincident AOD forecasted by SKIRON in the presence of several Saharan dust events.

\section{Datasets}

\section{2.a. The challenge of the comparisons}

The comparison of observations from instruments with different principles of operation, or between observations and forecasts are always challenging. In the current study we attempt to do both. The comparison of the AOD observations from a sun-photometer and the SKIRON model AOD forecasts require comparing a series of column integrated observations in the course of the day at one point in the surface with hourly column integrated forecasts over areas of $0.1^{\circ} \times 0.1^{\circ}$ around the point where the sun-photometer measurements are conducted. It is very similar in the case of the comparison with MODIS. We will be comparing a series of column integrated observations in the course of the day at one point in the surface with one daily column integrated observation (Terra passes from north to south across the equator in the morning while Aqua passes south to north over the equator in the afternoon) over areas of $1^{\circ} \times 1^{\circ}$ around the point where the sun-photometer measurements are conducted. That challenge is handled by testing several temporal and areal criteria for processing the AOD information, described below.

\section{2.b. Camagüey AOD measurements}

The sun-photometer CIMEL CE-318 installed at the Camagüey $\left(21.42^{\circ} \mathrm{N}, 77.84^{\circ} \mathrm{W}, 128\right.$ meters above sea level) is part of the Iberian Network for Aerosol Measurements (RIMA) which is 
federated into the Aerosol Robotic Network (AERONET). It was installed as result of a cooperation agreement for joint aerosol research between the University of Valladolid (UVA), Spain, and the Cuban Meteorological Institute (INSMET). The research is conducted by the Grupo de Óptica Atmosférica (GOA-UVA) and the Grupo de Óptica Atmosférica de Camagüey (GOAC-INSMET), formerly the Camagüey Lidar Station. The sun-photometer was operative from October $7^{\text {th }} 2008$. After the post calibration of the CIMEL \#353 and the reprocessing of the dataset the produced AOD by AERONET Version 2.0 showed very little changes with respect to the Version 1.5.

From the total of 746 instantaneous AOD measurements that passed the quality control and were processed in the Version 1.5 for the entire month of July 2009, only 11 did not passed the quality control required for version 2.0 , representing only the $1.5 \%$ of the observations reported before. The rest, 735 instantaneous AOD values $(98.5 \%)$, did not change in the Version 2.0 with respect to the Version 1.5. Table I lists the day's data that has been discarded in Version 2.0 and its effects with respect to Version 1.5.

Saharan dust events were measured for the first time with the sun-photometer installed at Camagüey, Cuba, in July 2009. A preliminary study has already been conducted [5]. We selected that period of time because of the presence of several events in the course of the month

The data was processed attending to three different criteria:

1. Hourly mean AOD (H-AODCMG): For each hour, within each day the mean AOD value was calculated. (239 values).

2. Daily mean AOD (D-AODCMG): For each day the mean AOD value was calculated. (29 values).

3. Daily maximum AOD (DMx-AODCMG): For each day the maximum AOD value was calculated. (29 values).

\section{2.c. SKIRON AOD forecasts dataset}

The SKIRON model has been operational for more than 10 years. Recently a new upgraded
Table I

AOD observations discarded per day and its effect in Version 2.0 with respect to Version 1.5 . Period July $1^{\text {st }}$ to $31^{\text {st }} 2009$.

\begin{tabular}{|c|c|l|}
\hline Day & \# Obs. & $\begin{array}{l}\text { Observed effect on Version 2.0 } \\
\text { AOD respect to Version 1.5 }\end{array}$ \\
\hline 2 & 1 & $\begin{array}{l}\text { Daily Mean AOD decrease in } \\
0.0089\end{array}$ \\
\hline 3 & 5 & No AOD values for that day \\
\hline 10 & 2 & No AOD values for that day \\
\hline 11 & 3 & $\begin{array}{l}\text { Daily Mean AOD decrease in } \\
0.0726\end{array}$ \\
\hline
\end{tabular}

version has been released [6]. For the present comparison we have used the SKIRON grid $\left(0.1^{\circ} \times 0.1^{\circ}\right)$ daily hourly forecasts of AOD at 500 $\mathrm{nm}$, from July $1^{\text {st }}$ to $31^{\text {st }}, 2009$. For the purposes of the comparison we selected the AOD values in the area of $0.5^{\circ} \times 0.5^{\circ}$ around the Camagüey sunphotometer site.

Different magnitudes of the AOD were calculated:

1. Hourly mean AOD (H-AODSK): Average of the AOD over the selected grid box for each one of the 24 hours each day (744 values).

2. Hourly maximum AOD (HMx-AODSK): Maximum AOD value over the selected grid box for each one of the 24 hours each day (744 values).

3. Daily means AOD (D-AODSK): Average of the AOD over the selected grid box and over the 24 hours each day (31 values).

4. Daily coincident maximum AOD (DMxAODSK): Maximum value of the forecasted AOD over the selected grid box for each one of the 24 hours each day for the same hour the daily maximum AOD registered at Camagüey (31 values).

\section{2.d. MODIS AOD measurements (Terra \& Aqua)}

We used Version 5.1 MODIS Terra and Aqua Daily Level-3 Data [7]. The data consists of daily AOD values from July 1 st to 31 st, 2009 with $1^{\circ}$ by $1^{\circ}$ resolution. The daily MODIS AOD values in the area of $3^{\circ} \times 3^{\circ}$ around the Camagüey sunphotometer site were averaged and also the daily maximum in that area was determined. The differences between the MODIS AOD (both for Aqua and Terra) daily areal means and the daily sun-photometer AOD means were calculated. Similarly the differences between the MODIS AOD daily areal maximums and the sun- 
photometer AOD daily maximums were determined.

\section{Results and discussion}

Figure 1 depicts on the top panel the set of instantaneous sun-photometer measurements for the whole period of study (black dots). In the middle panel the hourly mean values appear. In the bottom daily means and maximum are plotted.

\section{3.a. Comparison with coincident SKIRON forecasted AOD}

Figure 2 shows the differences between the hourly mean AOD measured at Camagüey $(\mathrm{H}-$ AODCMG) by sun-photometer and the hourly mean AOD (H-AODSK) forecasted by SKIRON. The last values were selected considering the values nearest in time to the hour the sunphotometer measurement was conducted (239 values). Those differences are depicted in blue. For illustrative purposes the values of $\mathrm{H}$ AODCMG are also plotted (green).
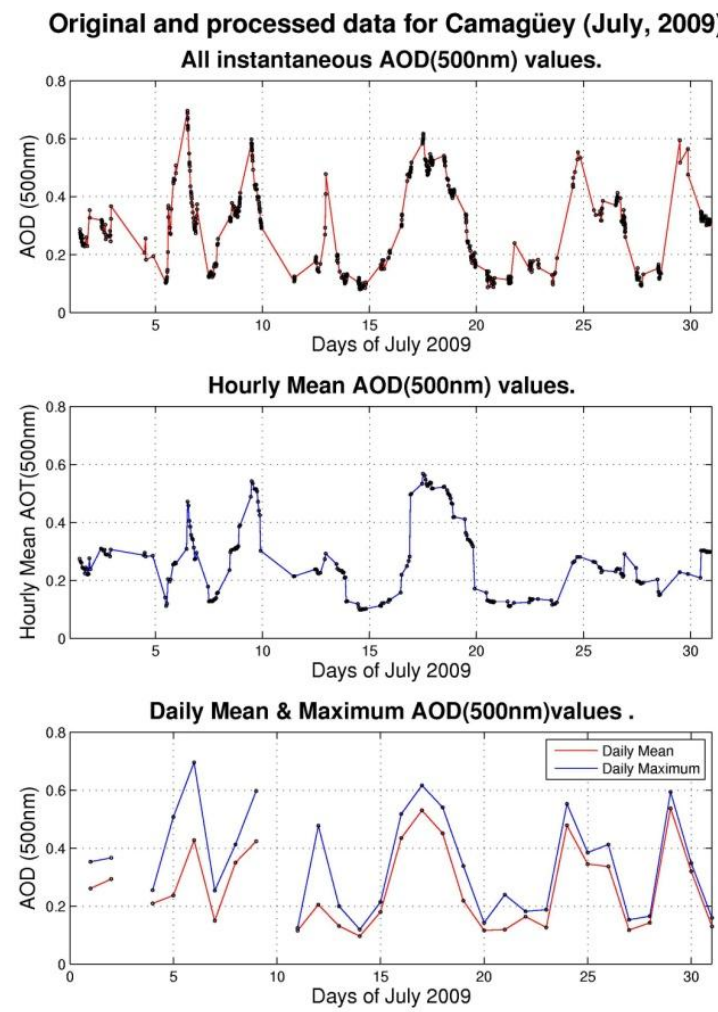

Fig. 1. Results of the processing of AOD sun-photometer measurements at Camagüey.
The higher differences in Fig. 2 are associated with the maximum values of the AOD registered by sun-photometer at Camagüey caused by Saharan aerosols, all then being negatives. This is a consequence of the Saharan aerosols AOD values forecasted by SKIRON being higher than the measured ones. In the cases of the lower AOD values measured, in absence of Saharan aerosols, the differences are mainly positive, revealing that in that case the AOD values forecasted by SKIRON are lower than the measured ones. In several cases the forecasted AOD values are very little, almost zero, producing differences of the same magnitude than the measured AOD. This feature is produced by the fact that SKIRON does not take into account the background aerosols (and its corresponding AOD) produced by local sources.

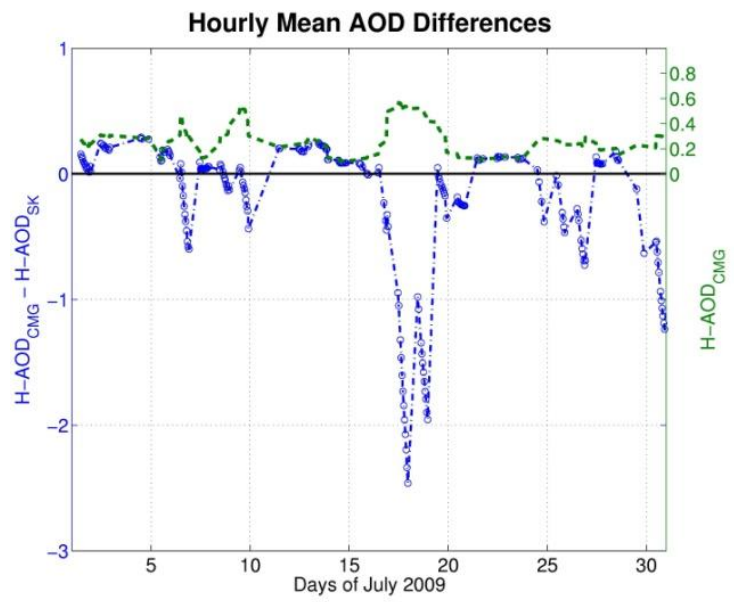

Fig. 2. Hourly mean AOD differences. Hourly mean sunphotometer AOD is superimposed (in green).

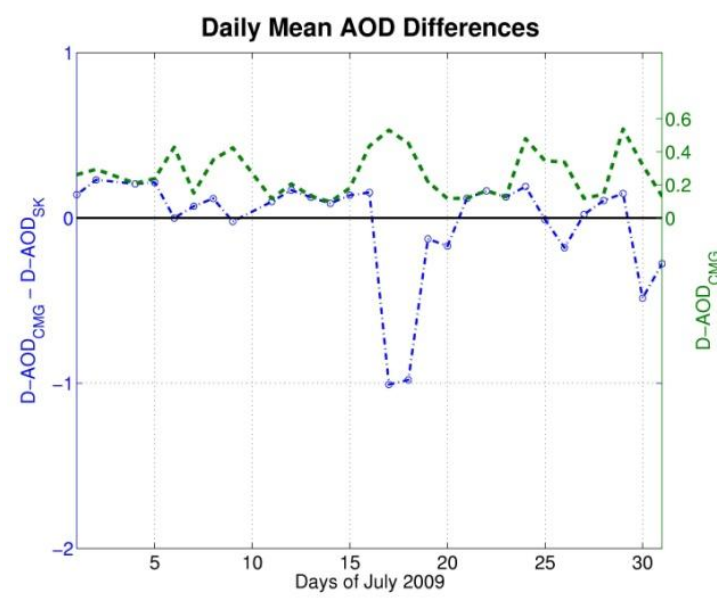

Fig. 3. Daily mean AOD differences (in blue). Daily mean sunphotometer AOD is superimposed (in green). 
Figure 3 shows the difference between the daily mean AOD measured (D-AODCMG) and the daily mean AOD forecasted by SKIRON (DAODSK). In general there is a decrease of the differences, with less negative cases, but the main features discussed in Fig. 2 still remain.

Figure 4 shows the difference between the measured daily maximum AOD (DMx-AODCMG) and the forecasted daily maximum AOD (HMxAODSK). It resembles almost the same behavior of the hourly mean AOD differences shown in Fig. 2.

Figure 5 shows the plot of the differences between the daily maximum AOD measured (DMx-AODCMG) and the forecasted daily maximum AOD at the same hour the maximum

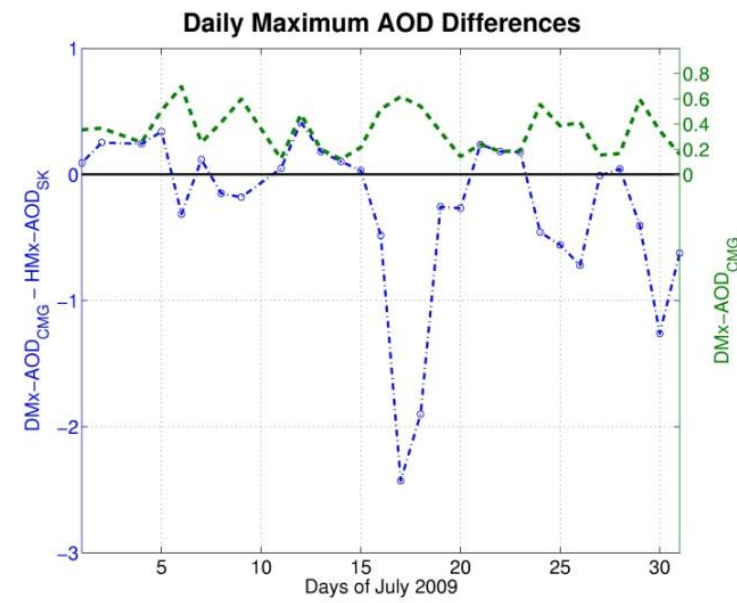

Fig. 4. Daily maximum AOD differences. Daily maximum sunphotometer AOD is superimposed (in green).

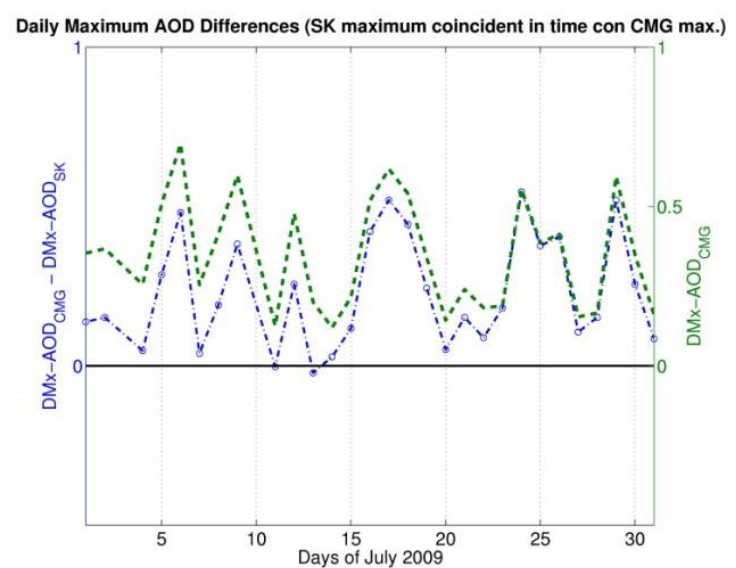

Fig. 5. Daily maximum AOD differences (in blue). Forecasted AOD maximum determined at the same hour than the maximum measured AOD. Daily mean sun-photometer AOD is superimposed (in green).
AOD was registered (DMx-AODSK). The differences are of the same order of magnitude than the DMx-AODCMG, due to the fact that the DMx-AODSK has very low values.

\section{3.b. Comparison with coincident MODIS measured AOD:}

Figure 6 shows the differences between the daily mean sunphotometer AOD and the daily mean areal MODIS-Aqua AOD on the top panel. Positive AOD differences coincide with the maximum of the sun-photometer AOD mean values, while the negative AOD differences take place at the minimum sun-photometer AOD mean values. That is, the mean areal MODISAqua AOD underestimates the high aerosols concentrations and overestimates the lower ones. A similar behavior could be appreciated appreciate that in the case of the SKIRON model in Fig. 3.

In the bottom panel of Fig. 6 , the differences between the daily maximum sun-photometer AOD and the daily areal maximum MODIS-Aqua
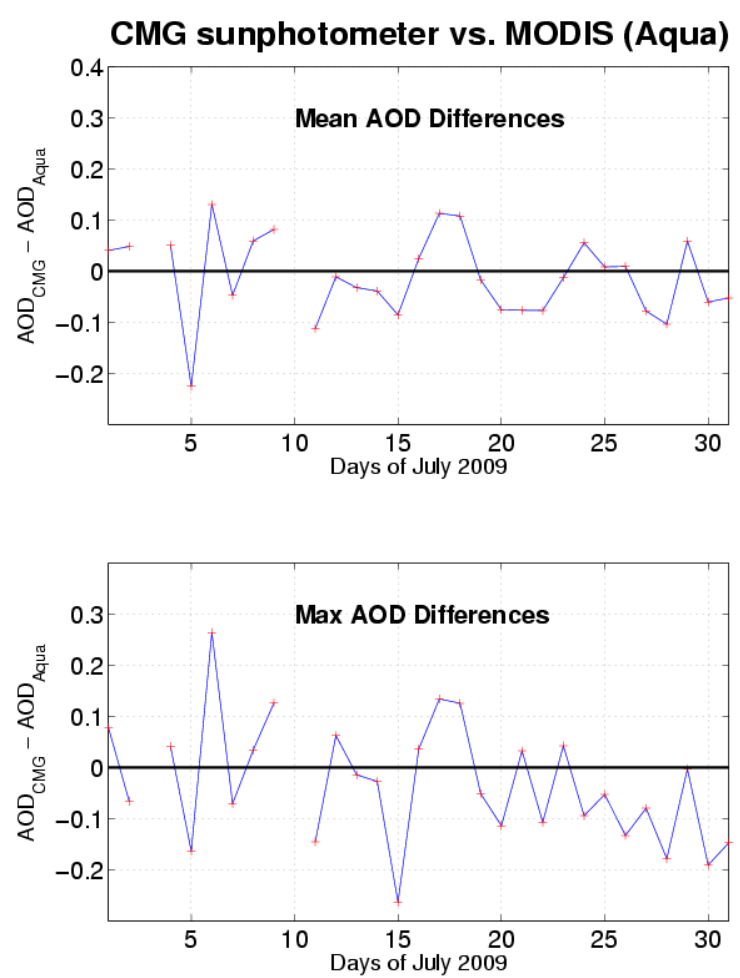

Fig. 6. AOD differences between sun-photometer and MODISAqua measurements. Top panel: differences between the daily mean sun-photometer AOD and the daily areal mean MODIS-Aqua AOD. Bottom panel: differences between the daily maximum sun-photometer AOD and the daily areal maximum MODIS-Aqua AOD. 
AOD are shown. In general it presents a similar behavior as in the top panel. If the former figure is compared with Fig. 4, similarities with the behavior described above will be also found.

Figure 7 shows a similar comparison as Fig. 6, but for the AOD measured by MODIS-Terra. The magnitudes of the differences in both panels are of the same order of magnitudes as the corresponding ones on Fig. 6. Also the values follow a similar pattern in the comparison of the AOD sun-photometer measurements with both satellite instruments AOD measurements, in general.

In Table II, the averages of differences for each one of the series of differences depicted in Figs. 6 and 7 are shown. The averages of the AOD differences between the sun-photometer and both satellite instruments for the whole month are also shown.

The averages of the differences are all negatives. This is because the magnitudes of the overestimation of the lower AOD sunphotometer values by Terra and Aqua are higher than the underestimation of the higher AOD sunphotometer values.
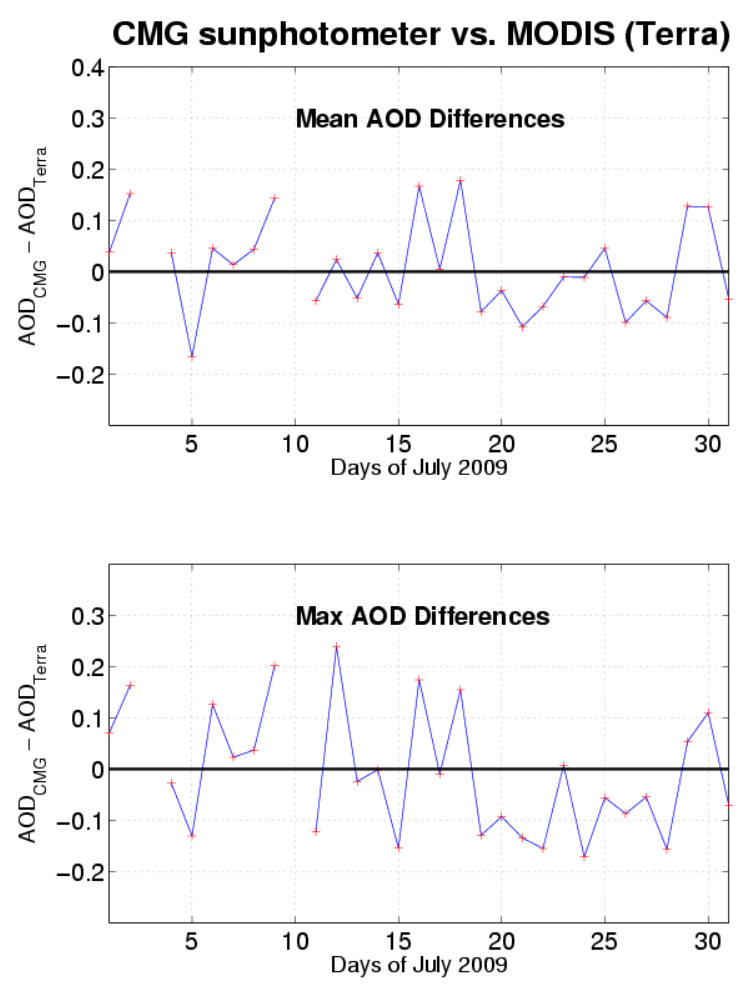

Fig. 7. Idem to Fig. 6, but for MODIS-Terra.
Table II

Averages of the AOD differences between the sunphotometer and both satellite instruments for the whole month. Absolute values of the differences are listed in the second line.

\begin{tabular}{|c|c|c|c|c|}
\hline & \multicolumn{2}{|c|}{ Aqua } & \multicolumn{2}{c|}{ Terra } \\
\hline & Mean & Max. & Mean & Max. \\
\hline Differences & -0.011 & -0.031 & -0.008 & -0.007 \\
\hline Abs. Diff. & 0.065 & 0.099 & 0.074 & 0.102 \\
\hline
\end{tabular}

\section{Conclusions}

Although the present study covers only the five Saharan dust events which took place on July 2009, some preliminary conclusions have been obtained. The daily average values of the sunphotometer measured AOD and modeled forecasted AOD show a better agreement than the rest of the combinations of AOD selection criteria tested, but still notable differences are present. The lack of background aerosols AOD in the forecast produces additional differences in the absence of Saharan dust. In the case of the long range transport of Saharan aerosols the forecasted AOD values are higher than the measured ones.

The differences between the daily mean sunphotometer AOD and the daily mean areal MODIS (both Terra and Aqua) AOD are lower than the differences between the daily maximum sun-photometer AOD and the daily areal maximum MODIS (both from Terra and Aqua) AOD. The mean areal AOD MODIS values (both for Terra and Aqua) underestimates the high aerosols concentrations and overestimates the lower ones, measured by the sun-photometer.

Further studies are under way to reach more conclusive results allowing designing and implementing an alert and tracking system for Saharan dust events across the Atlantic for the Wider Caribbean countries.

\section{Acknowledgements}

The leading author wants to thank Dr. Loraine Remer and her team for helping him learning about MODIS products, its origin and capabilities. Also the open and fruitful discussions with Dr. Remer during a one and half month visit to the Climate \& Radiation Laboratory at NASA-GSFC, provided a clear 
inside on how to advance in this type of studies under the current state of the art of the dust transport forecasting models and observing platforms. The visit was conducted under a Yoran Kaufman fellowship granted to the leading author by the UMBC and NASA-GSFC. The researchers and staff from both institutions were extremely helpful and kind, especially Dr. Raymond Hoff. His stimulus and persistence were decisive in making this visit possible. 